\section{A METHOD FOR ASSESSING THE VECTORIAL COMPETENCE OF FIELD COLLECTED CULICOIDES SPP. FOR BLUETONGUE VIRUS}

\author{
NINIO C.*, AUGOT D.*, FERTÉ H.*, BREARD E.**, \\ LILIN T.***, ZIENTARA S.**, MELLOR P.S.****, \\ DUFOUR B.***** \& DEPAQUIT J.*
}

Culicoides (Diptera: Ceratopogonidae) transmit Bluetongue virus (BTV). The identity of the competent species in the northern Europe is still uncertain. To help resolve this issue, two sheep were experimentally infected with BTV8. Viremia was confirmed by quantitative RT-PCR: $\mathrm{Ct}=32$ on day 4 post infection (p.i.) and 26 on day 5 p.i. On day 4 p.i. the sheep were placed individually into $4 \mathrm{~m}^{3}$ netted cages under $\mathrm{P} 3$. 192 field collected females captured at two cattle holdings in northern France were released into one cage, and 139 Culicoides, that emerged in the laboratory from breeding site material, such as manure, mud around trough and pounds, collected from both holdings, into the second. After 24 hours surviving Culicoides were collected and the blood-fed females were transferred into individual boxes. The blood engorged females were placed in an incubator $\left(21^{\circ} \mathrm{C}, 80 \%\right.$ humidity), supplied with a damp filter paper for egg laying and fed with sucrose solution.

Four field collected C. obsoletus s. 1., had taken a blood meal but none of the Culicoides that emerged in the laboratory was blood-fed. A blood-fed female laid eggs six days after blood feeding and was assayed for virus eight days post feeding. The other blood-fed midges were killed before egg laying. All surviving Culicoides were dissected for identification, thorax and abdomen being stored individually at $-80^{\circ} \mathrm{C}$, then were crushed in $300 \mu \mathrm{l} \mathrm{MEM.} 100 \mu \mathrm{L}$ was used for qRTPCR, and $100 \mu \mathrm{L}$ was inoculated intravenously into 10 days old embryonated chicken eggs. Three C. sonorensis, a major vector of BTV in the USA, were used as positive controls. They come from a colony kept in the Institute of Animal Health in Pirbright (UK) and were intrathoracically infected with BTV8. The female which laid eggs was weakly positive for BTV antigen using the qRT-PCR assay $(\mathrm{Ct}=36.9)$ but live virus was not isolated via the chicken egg inoculation assay. All other experimental Culicoides were negative in both assays, but all

\footnotetext{
* Usc Vecpar-AFSSA, JE 2533, Faculté de Pharmacie, Université de Reims Champagne-Ardenne, 51, rue Cognacq Jay, 51096 Reims, France.

*** AFSSA-LERPAZ, Unité de virologie, Maisons-Alfort, France.

**:* Centre de Recherches Biomédicales, École Nationale Vétérinaire, Maisons-Alfort, France.

***** Institute for Animal Health, Vector-borne Disease Programme, Ash Road, Pirbright, Woking, Surrey, GU24 ONF, UK.

**:*** Unité de recherche Epimai, École Nationale Vétérinaire, MaisonsAlfort, France.

Correspondence: Jérôme Depaquit.

E-mail: jerome.depaquit@univ-reims.fr
}

C. sonorensis were positive with Ct values ranging from 29 to 30 for individual midges, and between 18 and 19 for the qRT-PCR when run on the infected chicken eggs (which died at 2 and 3 days post inoculation).

The low feeding rate of the midges used in this study can be explained by the stress of captivity and an important percentage of Culicoides festivipennis, not known to feed on sheep. Based on a limited sampling, these results are not representative. Nevertheless, this method could be useful for future vectorial competence studies, though a major improvement in blood-feeding rates will be required to achieve meaningful results and detailed behavioural studies on Culicoides spp. are required to achieve this.

\section{ACKNOWLEDGEMENTS}

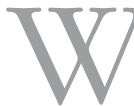
e would like to thank Simon Carpenter and Eva Veronesi, Institute for Animal Health, Vector-borne Disease Programme, who kindly provided us positive controls.

Reçu le $1^{\mathrm{er}}$ mars 2010

Accepté le 14 avril 2010

\begin{tabular}{|c|c|c|c|c|c|c|c|c|}
\hline \multirow{3}{*}{$\begin{array}{l}\text { Species } \\
\text { or species } \\
\text { group }\end{array}$} & \multicolumn{4}{|c|}{$\begin{array}{l}\text { Field collected } \\
\text { midges' batch }\end{array}$} & \multicolumn{4}{|c|}{ Emerged midges' batch } \\
\hline & \multicolumn{2}{|c|}{$\begin{array}{c}\text { Dead during } \\
\text { the } \\
\text { experiment }\end{array}$} & \multicolumn{2}{|c|}{$\begin{array}{l}\text { Killed after } \\
\text { experiment }\end{array}$} & \multicolumn{2}{|c|}{$\begin{array}{c}\text { Dead during } \\
\text { the } \\
\text { experiment }\end{array}$} & \multicolumn{2}{|c|}{$\begin{array}{l}\text { Killed after } \\
\text { experiment }\end{array}$} \\
\hline & 우 & $\sigma^{\pi}$ & 우 & $\sigma^{\pi}$ & 우 & $\pi$ & 우 & $\pi$ \\
\hline C. festivipennis & - & - & 1 & - & 17 & 55 & 22 & 12 \\
\hline C. circumscriptus & 11 & - & 1 & - & - & - & - & - \\
\hline $\begin{array}{l}\text { obsoletus } \\
\text { complex }^{1}\end{array}$ & 37 & 4 & $2^{*}$ & - & - & - & - & - \\
\hline C. dewulfi & 4 & 2 & $3^{* * *}$ & - & - & - & - & - \\
\hline $\begin{array}{l}\text { pulicaris } \\
\text { complex }^{2}\end{array}$ & 8 & 2 & 1 & - & 7 & - & 1 & - \\
\hline C.punctatus & 58 & 2 & 1 & - & - & - & 3 & 2 \\
\hline C. achrayi & 5 & 1 & - & - & - & 1 & 2 & - \\
\hline C. brunnicans & 3 & 1 & - & - & - & - & - & - \\
\hline C. vexans & 13 & - & - & - & - & - & - & - \\
\hline C. nubeculosus & 21 & 8 & 15 & - & - & 2 & 2 & - \\
\hline C. kibunensis & - & - & - & - & 1 & 4 & 3 & 1 \\
\hline C. stigma & - & - & - & - & - & - & 1 & - \\
\hline C. unknown ${ }^{3}$ & 7 & - & 1 & - & - & - & 2 & 1 \\
\hline Sub-total & 167 & 20 & 25 & - & 25 & 62 & 36 & 16 \\
\hline Total & & 21 & 2 & & & 13 & & \\
\hline
\end{tabular}

* Two females belonging to this species group had a blood meal at 4 days p.i. One of them laid eggs and and was slightly positive for BTV antigen by qRT-PCR. ${ }^{* *}$ Two females belonging to this species group had a blood meal at 4 days p.i.

${ }^{1}$ The Obsoletus complex includes C. obsoletus and C. scoticus females (males have all been identified as C. obsoletus). ${ }^{2}$ The Pulicaris complex includes $C$. pulicaris and C. lupicaris. ${ }^{3}$ Damaged individual not suitable for morphological identification.

Table - Sampling Culicoides species collected inside the net cages after having spent 24 hours with a viraemic sheep. 